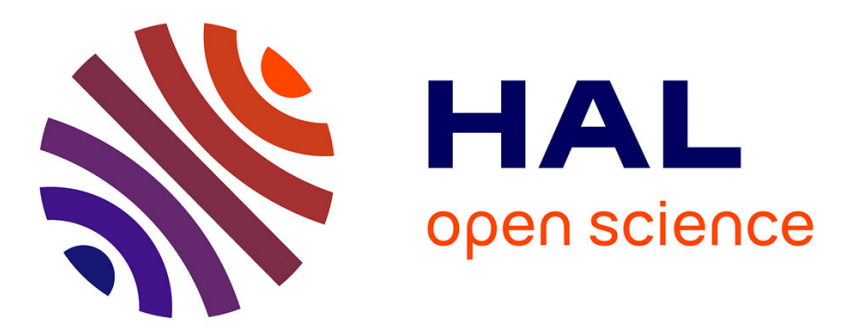

\title{
Grey mould development in greenhouse tomatoes under drip and furrow irrigation
}

Kamel Aissat, Philippe C. Nicot, Abdelhadi Guechi, Marc Bardin, Mohamed Chibane

\section{- To cite this version:}

Kamel Aissat, Philippe C. Nicot, Abdelhadi Guechi, Marc Bardin, Mohamed Chibane. Grey mould development in greenhouse tomatoes under drip and furrow irrigation. Agronomy for Sustainable Development, 2008, 28 (3), pp.403-409. 10.1051/agro:2008016 . hal-02661181

\section{HAL Id: hal-02661181 https://hal.inrae.fr/hal-02661181}

Submitted on 30 May 2020

HAL is a multi-disciplinary open access archive for the deposit and dissemination of scientific research documents, whether they are published or not. The documents may come from teaching and research institutions in France or abroad, or from public or private research centers.
L'archive ouverte pluridisciplinaire HAL, est destinée au dépôt et à la diffusion de documents scientifiques de niveau recherche, publiés ou non, émanant des établissements d'enseignement et de recherche français ou étrangers, des laboratoires publics ou privés.

$$
\text { Copyright }
$$




\title{
Grey mould development in greenhouse tomatoes under drip and furrow irrigation
}

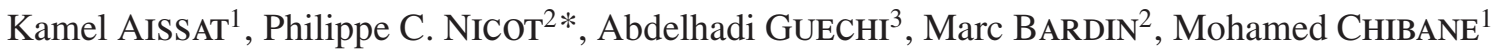 \\ ${ }^{1}$ Université A/Mira, Faculté des Sciences de la Nature et de la Vie, Laboratoire de Microbiologie Appliquée, Bejaia, 06000, Algeria \\ ${ }^{2}$ INRA, UR407 Pathologie Végétale, 84140 Montfavet, France \\ ${ }^{3}$ Université Ferhat Abbas, Département de Biologie, Sétif, 19000, Algeria
}

(Accepted 12 March 2008)

\begin{abstract}
Several methods can be used to provide water to plants in cropping systems where irrigation is necessary. For instance, drip irrigation has recently received much attention due to its advantages for water conservation. The type of irrigation can also impact the development of several pathogens responsible for soilborne diseases. Here, we studied the effect of drip irrigation and furrow irrigation on the development of grey mould, caused by the airborne fungus Botrytis cinerea, on tomato plants. A field experiment was conducted in 2004 in five unheated greenhouses. Plants were examined individually every 8 days and the proportion of plants attacked by grey mould on leaves, stems or fruits was recorded from the end of March until the end of June. Our results show that the attacks of Botrytis on the stems occurred earlier in furrow irrigation, 98.8 days after planting on average, than in drip irrigation: 106.3 days after planting. The kinetics of plant infection on stems, leaves and fruits were higher under furrow than under drip irrigation. Disease severity was measured by the average number of stem lesions per plant. Disease severity was higher in plants under furrow than under drip irrigation, reaching 1.32 and 0.99 , respectively, at the end of June. Plant mortality due to grey mould was first recorded at 94 and 110 days after planting, respectively, in the furrow- and in the drip- irrigated greenhouses. These results suggest that drip irrigation could be a useful tool for the implementation of integrated protection schemes and for reducing the use of pesticides in unheated tomato greenhouses. They may also provide an additional incentive for growers to switch from furrow to drip irrigation in sheltered tomato production.
\end{abstract}

tomato / Lycopersiconesculentum / Botrytiscinerea / Algeria / sheltered crops / irrigation

\section{INTRODUCTION}

Commercial vegetable production in semi-arid regions such as Northern Algeria relies on irrigation. Both sprinkler and furrow irrigation are commonly used in Algeria, as in other parts of the world (Ashcroft et al., 2003; Hanson and May, 2006; Locascio, 2005; Yohannes and Tadesse, 1998). However, drip irrigation is increasingly being adopted by farmers worldwide, including in unheated tomato greenhouses. Studies comparing sprinkler or furrow irrigation with drip irrigation in tomatoes and in other crops have shown that drip systems generally have better water-use efficiency and often provide higher yields (Ashcroft et al., 2003; Flowers et al., 2005; Hebbar et al., 2004; Singandhupe et al., 2003; Tiwari et al., 2003; Yohannes and Tadesse, 1998).

Irrigation methods may also have significant effects on plant health (Rotem and Palti, 1969). Sprinkler irrigation has been shown to foster the development of water-dependent plant pathogens (Rotem et al., 1970). Furrow irrigation has been associated with salt accumulation, resulting in seedling mortality, in several crops, including tomato and pepper (Miyamoto et al., 1986). Furrow irrigation is also considered to foster the development of economically important soilborne diseases. In studies conducted on field tomatoes under furrow irrigation, root rot caused by Phytophthora parasitica developed faster and disease severity was greater in plots that received prolonged irrigation treatments, in comparison with less abundant irrigation (Ristaino et al., 1988). Similar results were obtained with root and fruit rot, caused by P. capsici on pepper (Café-Filho et al., 1995). In comparative studies of drip and furrow irrigation, the incidence of Phytophthora root rot was greater and the marketable yield of pepper was lower under furrow than under drip irrigation (Xie et al., 1999). Similarly, on lettuce crops, the incidence of lettuce drop caused by Sclerotinia minor and the severity of corky root caused by Rhizomonas suberifasciens were significantly higher under

* Corresponding author: philippe.nicot@avignon.inra.fr 
furrow than under drip irrigation (Subbarao et al., 1997; Wu and Subbarao, 2003).

In contrast with these results, switching from furrow to drip irrigation may not always have beneficial effects on crop health. Nischwitz et al. (2004) reported an increase in charcoal rot, caused by Macrophomina phaseolina, in Arizona fields where melon growers switched from furrow to drip irrigation systems. They found significantly higher inoculum levels in soil samples taken from drip-irrigated than from furrow-irrigated fields and suggested that drip irrigation may contribute to higher disease incidences. For other soilborne diseases, the impact of the irrigation method may not be so important. For example, Xiao et al. (1998) reported no significant differences in incidence or severity of Verticillium wilt between drip- or furrow-irrigated cauliflower plots in California.

In contrast with soilborne diseases, little is known on possible effects of drip irrigation systems on air-disseminated plant pathogens and diverging results have been reported. A reduction of downy mildew of lettuce caused by Bremia lactucae was observed in crops grown under drip irrigation, compared with furrow irrigation, in California's central coast area (Scherm and van Bruggen, 1995). However, in another study in the Salinas Valley, no significant differences were found between the two types of irrigation (Subbarao et al., 1997). Similarly, Allen et al. (1992) reported that the incidence of bacterial blight of cotton caused by Xanthomonas campestris pv. malvacearum was neither greater nor lower in furrow- than in drip-irrigated plots in different years.

In sheltered vegetable culture in the Mediterranean area, grey mould, caused by Botrytis cinerea, is one of the most serious airborne diseases both in terms of incidence and in terms of the difficulties encountered by growers for its management (Elad and Shtienberg, 1995). Although published data on the prevalence of this disease in Algeria are lacking, preliminary surveys conducted by our group in vegetable production areas of northeastern Algeria have shown that grey mould is also a major plant health concern. As water may play an important role in the epidemiology of this disease (Holz et al., 2004; O'Neill et al., 1997), we hypothesised that the type of irrigation system could influence the development of this disease, and that changing from traditional furrow irrigation to drip irrigation could help farmers reduce its impact.

The objective of this work, therefore, was to compare the development of grey mould and its impact on plant mortality in sheltered tomato crops under furrow and drip irrigation in commercial conditions.

\section{MATERIALS AND METHODS}

\subsection{Experimental site}

The experiment was conducted in five unheated tunnel greenhouses located on a private farm in Bejaia, on the Mediterranean agricultural coastal band of northern Algeria, where protected vegetable production is dominant. Each unheated greenhouse was $50 \times 8 \mathrm{~m}$ and consisted of $3 \mathrm{~m}$-high metal arches covered with a plastic film. The greenhouses

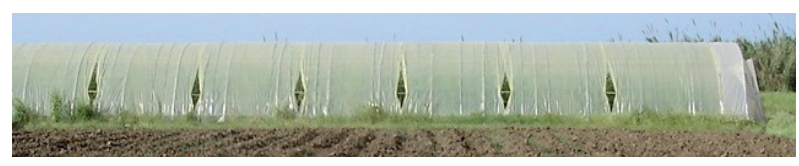

Figure 1. Unheated tomato greenhouse showing the vertical side openings used by growers for passive ventilation.

were oriented north-south, with the sea shore approximately 50 metres to the north. Passive ventilation occurred through the doors (one at each extremity of the greenhouse) and through vertical side openings obtained by separating adjacent plastic sheets along the tunnel (Fig. 1).

\subsection{Field management}

Tomato seedlings (Lycopersicon esculentum L. cultivar Agora, Vilmorin, France) were produced locally in a small tunnel and transplanted into the five greenhouses at age 60 days, on February 1st, 2004. Each greenhouse contained 770 seedlings arranged in 7 lines, $0.8 \mathrm{~m}$ apart. In a line, the distance between two seedlings was $0.4 \mathrm{~m}$, resulting in an average planting density of ca. 1.9 plants. $\mathrm{m}^{-2}$.

Throughout the season, three types of fertilisers were applied to all greenhouses according to the stage of development of the plants. Basic fertiliser, NPK (15-15-15), was applied prior to plantation during tilling at a rate of $50 \mathrm{~kg}$ per greenhouse. Then, $10 \mathrm{~kg}$ of ammonitrate $(33.5 \% \mathrm{w})$ were applied at the time of the first hoeing, three weeks after plantation. This application was repeated in early April at the beginning of fructification and in early May at the beginning of harvest.

Weeding was carried out by hand three weeks after plantation. Due to heavy development of weeds in the greenhouses under furrow irrigation, this operation was repeated throughout the season in those greenhouses, every two weeks until the first harvest and then once a month during harvest. In greenhouses under furrow irrigation, hand weeding was systematically accompanied by hoeing and ridging of the plants, to loosen the soil and protect the root systems and to maintain the shape of the furrows. Pesticides were applied on several occasions by the farmers. Benomyl, folpel+metalaxyl, maneb, penconazole and sulphur were used to control fungal pathogens, and methomyl was used against insect pests.

In all greenhouses, the plants were trellised, and starting in early April, axillary buds were removed every 2 weeks to maintain a single stem. The leaves located below the first flower truss were removed after the first harvest. To reduce slightly the total amount of foliage, further leaf pruning was done following the successive harvests on subsequent trusses, with only one leaf removed from a plant each time.

Throughout the growing season, water was provided either as furrow or as drip irrigation. Furrow irrigation was applied at weekly intervals, amounting to a minimum of $20 \mathrm{~L}$ of water per plant in a week. Drip irrigation was applied for 2 hours twice weekly, amounting to approximately $8 \mathrm{~L}$ of water per plant in a week. 


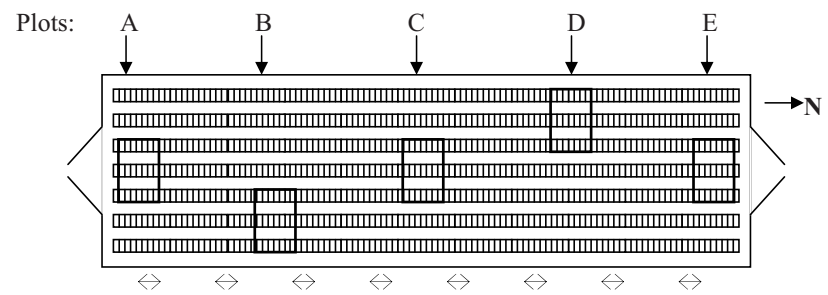

Figure 2. Schematic representation of a greenhouse showing the 7 rows of plants (each represented by a small rectangle) and five plots (A to E), each represented by a large rectangle. The double arrows $(\leftrightarrow)$ indicate the locations of the side openings as shown in Figure 1.

\subsection{Experimental design and statistical analyses}

Among the five commercial greenhouses available for the study, two were under furrow irrigation and three under drip irrigation. In each greenhouse 5 plots were delimited, each containing 21 plants over 3 adjacent rows (Fig. 2). The greenhouse environment is known for the heterogeneous spatial distribution of its microclimate (Boulard et al., 1999). For a climatedependent disease such as grey mould, this is likely to have implications in terms of disease development. As we did not have adequate equipment to monitor this heterogeneity during the experiment, the plots were arranged relative to sunlight distribution and to possible air currents linked to doors and side openings, to maximise the exposure to this potential heterogeneity. In each plot, all the plants were examined individually every 8 days and the incidence of grey mould on leaves, stems and fruits was recorded from the end of March until the end of June (12 observations). Other diseases, such as powdery mildew, Cladosporium leaf mould and downy mildew occurred occasionally on the foliage. As these diseases were efficiently controlled by the growers, no epidemic development was observed and their incidence was not monitored.

Statistical analyses were carried out using appropriate modules of Statistica (Statsoft, Inc., Tulsa, USA), and included Student's t tests, analyses of variance, and when needed, Newman and Keuls' test for multiple comparisons of means. In all analyses, the elementary replicate was the greenhouse. To compute the Student's t statistics, the values of observations for all five plots of a greenhouse were averaged. Analysis of variance was used to test specific plot effects within the greenhouses. To facilitate hypothesis testing concerning the kinetics of disease development, studies in plant epidemiology are commonly carried out on the areas under the disease progress curves (Madden et al., 2007). When disease assessment is realised at regular intervals, this area can be computed as AUDPC $=\left[Y_{1} / 2+\sum_{2}^{n-1} Y_{j}+Y_{n} / 2\right] \times I$, where $Y_{j}$ is the observed disease level at the $j$ th observation time, $n$ is the total number of observations, and $I$ the number of days between each observation. In our study, we computed these values for $12 \mathrm{ob}-$ servation dates, at 8-day intervals, during the period from 53 to 141 days after the plantation of seedlings inside the greenhouses.

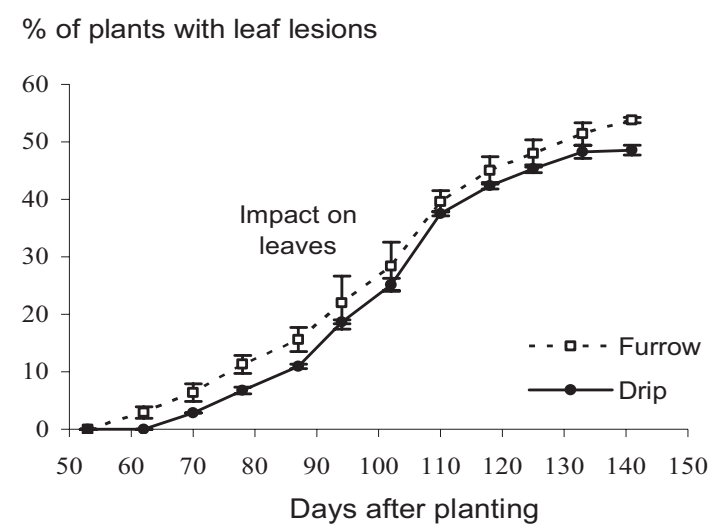

$\%$ of plants with stem lesions

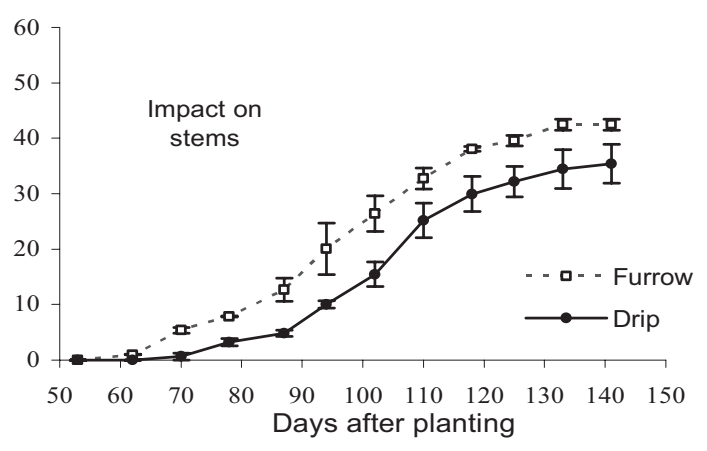

$\%$ of plants with fruit lesions

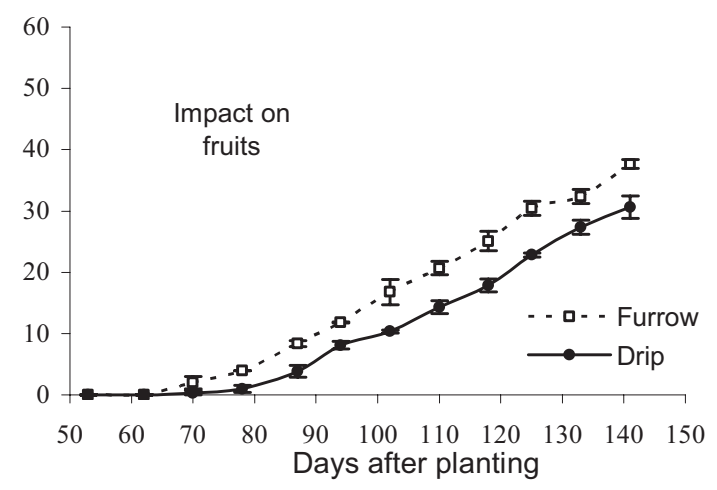

Figure 3. Kinetics of disease incidence on leaves, stems and fruits in tomato greenhouses, as affected by irrigation type. The time scale is measured in days after the 60-day-old tomato seedlings were transplanted into the greenhouses. Vertical bars represent the standard error of the means (averages of three values for drip irrigation and of two values for furrow irrigation).

\section{RESULTS AND DISCUSSION}

\subsection{Effect of irrigation type on disease incidence}

Symptoms of grey mould were first detected in the furrowirrigated greenhouses, at 62 days after planting on leaves and on stems and at 70 days after planting on fruits (Fig. 3). In the drip-irrigated greenhouses, the first attacks were observed 
Table I. Effect of the irrigation system on the kinetics of disease development, represented by the areas under the disease progress curves.

\begin{tabular}{|c|c|c|c|}
\hline \multirow{2}{*}{$\begin{array}{l}\text { Attacked } \\
\text { plant organ }\end{array}$} & \multicolumn{2}{|c|}{ Type of irrigation } & \multirow[b]{2}{*}{$P$ value $^{2}$} \\
\hline & Drip & Furrow & \\
\hline Stem & $1388.6^{1}$ & $1979.1^{1}$ & 0.02 \\
\hline Fruit & 969.5 & 1360.9 & 0.004 \\
\hline Leaf & 2097.3 & 2381.9 & 0.14 \\
\hline
\end{tabular}

${ }^{1}$ Each figure represents the mean value of the Areas Under the Disease Progress Curves computed from the date of plantation to the end of the trials as indicated in Figure 3.

${ }^{2}$ Student's t test of equality of means (averages of three values for drip irrigation and two values for furrow irrigation)

Table II. Effect of the irrigation system on the precocity of disease onset.

\begin{tabular}{lccc}
\hline Attacked & \multicolumn{2}{c}{ Type of irrigation } & \\
\cline { 2 - 3 } plant organ & Drip & Furrow & $P$ value \\
\hline Stem & $106.3^{1}$ & $98.8^{1}$ & 0.02 \\
Fruit & 112.7 & 108.4 & 0.15 \\
Leaf & 101.4 & 101.2 & 0.98 \\
\hline
\end{tabular}

${ }^{1}$ Each figure represents the relative age of the plants (in days after plantation of the 60-day-old seedlings in the tunnels) at the time when they were first attacked. The plants that remained healthy were excluded from this analysis.

${ }^{2}$ Student's $t$ test of equality of means (averages of three values for drip irrigation and two values for furrow irrigation).

later, and throughout the growing season their incidence remained lower, than in furrow-irrigated greenhouses.

The contrast between furrow and drip irrigation was highest when comparing the incidence of stem and fruit lesions. Statistical analyses conducted on the areas under the disease progress curves indicated that the differences in the kinetics of disease development were significant $(P<0.05)$ for attacks on stems and fruits, but not on leaves (Tab. I). Similar effects of irrigation type were observed in a detailed analysis of the time of disease onset for individual plants. The average age of a plant when it became diseased was significantly lower $(P<0.05)$ in furrow- than in drip-irrigated greenhouses when considering symptoms on stems, but not for symptoms on leaves and fruits (Tab. II). On average, the stems were attacked later than the leaves in drip-irrigated greenhouses, while the opposite was observed under furrow irrigation.

In other studies, a similarly strong impact of the type of irrigation on disease development has been reported in two other vegetable crops for several other diseases. In pepper and lettuce, it was shown that downy mildew and certain soilborne diseases were less prevalent in drip-irrigated than in sprinkleror furrow-irrigated crops (Wu et Subbarao, 2003; Xie et al., 1999; Subbarao et al., 1997; Scherm and van Bruggen, 1995). Contrarily to the case of soilborne diseases, a direct effect of soil water on the pathogen is unlikely in the case of the present study, as the inoculum of $B$. cinerea consists essentially of airborne conidia, which are produced abundantly on diseased plant tissue and are easily transported by air currents. On the other hand, the first steps of pathogenesis in grey mould (spore germination and establishment of a small primary colony on the host plant) are known to be highly dependent on the occurrence of high relative humidity (Holz et al., 2004; O'Neill et al., 1997).

One possible hypothesis to explain the difference in grey mould development in greenhouses under drip and furrow irrigation is that sufficient differences in microclimatic conditions may have occurred in the vicinity of the target plant organs. In a study on field lettuce in California, Scherm and van Bruggen (1995) measured significantly higher relative humidity at crop level in plots under furrow irrigation than in plots under drip irrigation. This could not be tested directly in our study, as we lacked the substantial resources that would have allowed monitoring basic microclimatic parameters of the canopy of the greenhouses throughout the season. However, several points support this hypothesis. Firstly, much more water was applied on the soil surface in the furrow- than in the drip-irrigated greenhouses. Secondly, we observed an abundant development of weeds in the furrow-irrigated system, as described for field tomatoes in California (Sutton et al., 2006). These weeds may both have provided additional water vapour and a hindrance to air circulation in the lower part of the canopy. Another element in support of our hypothesis is the fact that the contrast between drip- and furrow-irrigated greenhouses was higher for the symptoms on stems and fruits and lower for the attacks on leaves. While lesions on leaves may be found at all heights in the canopy, stem lesions originating from infection of leaf pruning wounds are usually located on the lower part of the plant, near the ground, where a putative difference in relative humidity between furrow and drip irrigation would be greater.

\subsection{Effect of irrigation on disease severity on stems and on plant mortality}

During the growing season, the occurrence of leaf pruning and the regular removal of axillary buds by the growers provided many wounds likely to become infected by $B$. cinerea and to result in the development of stem lesions. Occasionally, expansion of lesions on leaves or fruits also resulted in stem infections, as described by Shtienberg et al. (1998) for similar types of tomato production systems. Overall, multiple stem infections on individual plants were not rare, and the average number of stem lesions per plant was used as a measure of disease severity. Throughout the experiment, disease severity remained systematically higher on plants under furrow than under drip irrigation (Fig. 4).

Statistical analysis of the areas under the disease progress curves indicated that this difference was significant $(P=0.016)$, with average values of 1101 and 687 for greenhouses under furrow and drip irrigation, respectively.

The expansion of stem lesions may typically result in girdling and death of the plants. In our trials, plant mortality was first recorded at 94 and 110 days after planting, respectively, in the furrow- and in the drip-irrigated greenhouses. 
Average number of stem lesions per plant

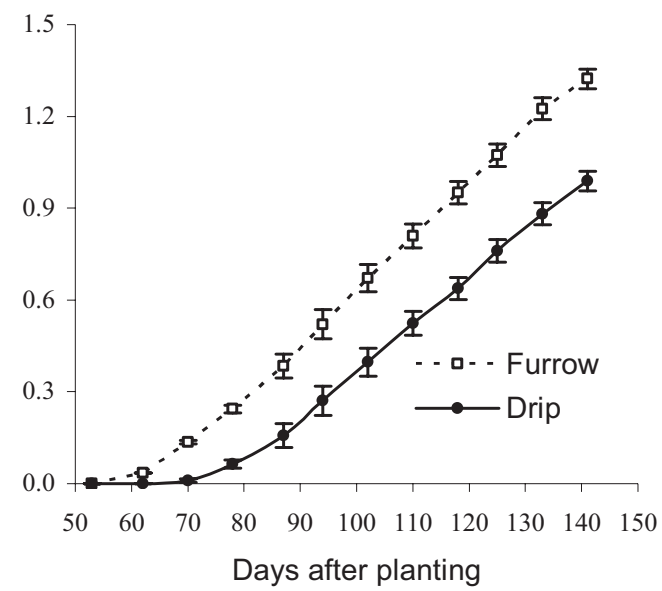

Figure 4. Evolution of severity of attacks on stems as affected by irrigation type. Vertical bars represent the standard error of the mean (averages of three values for drip irrigation and two values for furrow irrigation).

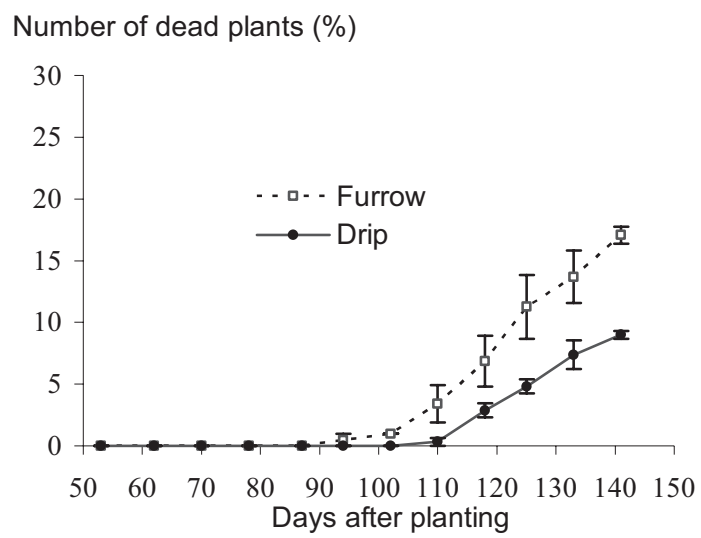

Figure 5. Kinetics of plant mortality due to grey mould as affected by irrigation type. Vertical bars represent the standard error of the mean (averages of three values for drip irrigation and two values for furrow irrigation).

On average, the incidence of plant death remained higher under furrow than under drip irrigation and reached $17.1 \%$ and $9.0 \%$, respectively, by the end of the trial (Fig. 5). This difference in the kinetics of mortality was statistically significant $(P=0.02)$, as indicated by analysis of the areas under the disease progress curves.

\subsection{Spatial heterogeneity of disease development and plant mortality inside the greenhouses}

In the course of the disease assessment campaign, a lack of homogeneity in the spatial distribution of diseased or dead plants was gradually noticed in all greenhouses. A plot effect was formally tested by analysis of variance of the areas under the disease progress curves for all indicators of disease incidence and severity and for the incidence of plant mortality.
A significant effect was found $(P$ values $<0.05)$ in all cases but one (Tab. III).

Further analysis, using the test of Newman and Keuls for multiple comparison of means, allowed us to identify spots in the greenhouse with significantly different $(P<0.05)$ levels of disease or plant mortality. Both in furrow- and in drip-irrigated greenhouses, disease development was by far the highest in plots "C", located in the centre of the greenhouse, and it tended to be lower in plots "E" and in plots "A", located near the entrances of the greenhouse, than in plots "B" and plots "D", located deeper inside the greenhouses. Some of these differences among plots "A", "B", "D" and "E" were statistically significant for three of the five disease indicators in the drip-irrigated greenhouses (Tab. III).

To explain this spatial heterogeneity of disease development, it is tempting to hypothesise that air movement was reduced in the centre of the greenhouses because of the rapid and abundant growth of the canopy, and as a consequence, relative humidity was higher and more conducive to disease. Similarly, one can expect that more air movement and consequently lower relative humidity occurred near the doors of the greenhouses, which were frequently opened during the growing season. This hypothesis is compatible with existing information on the heterogeneity of distribution of air movement and other physical parameters in different types of greenhouses (Boulard et al., 1997, 2004; Wang and Boulard, 2000). Furthermore, comparisons of aeration regimes in tomato greenhouses in Portugal showed that enhanced aeration decreased the development of grey mould (Abreu et al., 1994; Meneses et al., 1994).

In relation to this spatial heterogeneity in disease development, the contrast between drip and furrow irrigation was also not spatially uniform within the greenhouse. It was the lowest in central plots " $\mathrm{C}$ " and the highest in plots " $\mathrm{A}$ " and "E" located near the doors. These results are compatible with the hypothesis formulated in Section 3.2 on the suspected impact of irrigation type on the microclimate in the greenhouse. Under our hypothesis, it would not be illogical that differences in relative humidity due to the irrigation system could have less effect in already very humid conditions than in less confined areas of the greenhouses.

\section{CONCLUSION}

Despite the importance of water-saving irrigation for durable agriculture in subtropical and Mediterranean regions, our knowledge on the impact of drip irrigation on plant diseases has been mostly limited to a few soilborne diseases in field vegetable crops. The present study revealed clear differences in the development of an economically important airborne disease in tomato greenhouses conducted under furrow and drip irrigation. To our knowledge, it also provided the first formal data on the kinetics of Botrytis epidemics and the prevalence of the disease in sheltered vegetable crops in Algeria. During the entire span of the trial, all indicators of grey mould incidence, severity and plant mortality remained 
Table III. Heterogeneity of disease development and plant mortality depending on the location of plots within the greenhouses.

\begin{tabular}{|c|c|c|c|c|c|}
\hline \multirow{2}{*}{$\begin{array}{l}\text { Type of greenhouse } \\
/ \text { Plots }^{1}\end{array}$} & \multicolumn{3}{|c|}{ Disease incidence on } & \multirow{2}{*}{$\begin{array}{l}\text { Disease severity } \\
\text { on stems }\end{array}$} & \multirow{2}{*}{$\begin{array}{c}\text { Plant } \\
\text { mortality }\end{array}$} \\
\hline & stems & leaves & fruits & & \\
\hline Furrow irrigation $\mathrm{A}$ & $1370^{3} a^{4}$ & $2410 \mathrm{ab}$ & $1630 \mathrm{a}$ & $1050 \mathrm{a}$ & $200 \mathrm{a}$ \\
\hline B & $1886 \mathrm{a}$ & $2792 \mathrm{ab}$ & $1027 \mathrm{a}$ & 948 a & $334 \mathrm{a}$ \\
\hline $\mathrm{C}$ & $4164 \mathrm{~b}$ & $3520 \mathrm{~b}$ & $1944 \mathrm{a}$ & $1852 \mathrm{~b}$ & $851 \mathrm{~b}$ \\
\hline $\mathrm{D}$ & $1362 \mathrm{a}$ & $1515 \mathrm{a}$ & $1638 \mathrm{a}$ & $900 \mathrm{a}$ & $210 \mathrm{a}$ \\
\hline E & $1114 \mathrm{a}$ & $1673 \mathrm{a}$ & $1565 \mathrm{a}$ & $756 a$ & $213 a$ \\
\hline$P$ value $^{2}$ & $P=0.0003$ & $P=0.0002$ & $P=0.07$ & $P=0.01$ & $P=0.0003$ \\
\hline Drip irrigation $\mathrm{A}$ & $973 \mathrm{ab}$ & $1611 a b$ & $822 \mathrm{a}$ & $537 \mathrm{~b}$ & $108 \mathrm{a}$ \\
\hline B & $1365 \mathrm{~b}$ & $2470 \mathrm{~b}$ & $870 \mathrm{a}$ & $731 \mathrm{~b}$ & $165 \mathrm{a}$ \\
\hline $\mathrm{C}$ & $2762 \mathrm{c}$ & $3613 \mathrm{c}$ & $1612 b$ & $1296 \mathrm{c}$ & $375 \mathrm{~b}$ \\
\hline $\mathrm{D}$ & $1333 \mathrm{~b}$ & $1600 \mathrm{ab}$ & $832 \mathrm{a}$ & $589 \mathrm{~b}$ & $127 \mathrm{a}$ \\
\hline $\mathrm{E}$ & $510 \mathrm{a}$ & $1193 \mathrm{a}$ & $711 \mathrm{a}$ & $285 \mathrm{a}$ & $20 \mathrm{a}$ \\
\hline$P$ value $^{2}$ & $P=0.0001$ & $P=0.04$ & $P=0.003$ & $P=0.00006$ & $P=0.0003$ \\
\hline
\end{tabular}

${ }^{1}$ The location of the plots (A, B, C, D and E) inside the greenhouses is indicated in Figure 2.

${ }^{2} P$ values for the tests of Fisher in analyses of variance.

${ }^{3}$ Each figure represents the mean value of the Areas Under the Disease Progress Curves computed from the date of plantation to the end of the trials as indicated in Figure 3.

${ }^{4}$ Within each column for a given type of irrigation, the numbers followed by different letters are significantly different $(P<0.05)$ according to Newman-Keuls' Test for multiple comparison of means.

lower for greenhouses under drip irrigation than for those under furrow irrigation. In addition, we observed that weed development was very limited in the drip-irrigated greenhouses, while recurrent and abundant weed development occurring in the furrow-irrigated greenhouses required multiple interventions, and constituted potential reservoirs for pests and plant pathogens. These results suggest that drip irrigation could be a useful tool for the implementation of integrated protection schemes and for reducing the use of pesticides in tomato greenhouses. Combined with other advantages related to water conservation, these considerations could provide an incentive for greenhouse tomato growers in Algeria, and possibly in other Mediterranean countries, to make more use of drip irrigation.

\section{REFERENCES}

Abreu P.E., Monteiro A.A., Meneses J.F. (1994) Response of unheated plastic covered greenhouse tomatoes during the cool season and under two different natural ventilation methods, Acta Hort. 366, 195200.

Allen S.J., Hodgson A.S., Constable G.A. (1992) The effects of various agronomic practices on the incidence of bacterial blight of cotton, Plant Prot. 7, 55-58.

Ashcroft W.J., Bieche B., Branthome X., Qassim A., Aleemullah M., Hickey M.J., Hulme J., Hoogers R. (2003) Irrigation best management practices - The Australian experience, Acta Hort. 613, 147150 .

Boulard T., Feuilloley P., Kittas C. (1997) Natural ventilation performances of six greenhouse and tunnel type, J. Agr. Eng. Res. 67, 249-266.

Boulard T., Wang S., Haxaire R., Papadakis G., Mermier M. (1999) Air flow, temperature and humidity patterns in a greenhouse tunnel, Acta Hort. 507, 51-59.

Boulard T., Fatnassi H., Roy J.C., Lagier J., Fargues J., Smits N., Rougier M., Jeannequin B. (2004) Effect of greenhouse ventilation on humidity of inside air and in leaf boundary-layer, Agr. Forest Meteorol. 125, 225-239.

Cafè-Filho A.C., Duniway J.M., Davis R.M. (1995) Effects of the frequency of furrow irrigation on root and fruit rots of squash caused by Phytophthora capsici, Plant Dis. 79, 44-48.

Elad Y., Shtienberg D. (1995) Botrytis cinerea in greenhouse vegetables: Chemical, cultural, physiological and biological controls and their integration, Integrated Pest Manag. Rev. 1, 15-29.

Flowers T.J., Ragab R., Malash N., Abdel Gawad G., Cuartero J., Arslan A. (2005) Sustainable strategies in salt-prone Mediterranean: SALMED, Agr. Water Manage. 78, 3-14.

Hanson B.R., May M.D. (2006) Crop evapotranspiration of processing tomato in the San Joaquin Valley of California, USA, Irrig. Sci. 24, 211-221.

Hebbar S.S., Ramachandrappa B.K., Nanjappa H.V., Prabhakar M. (2004) Studies on NPK drip fertigation in field grown tomato (Lycopersicon esculentum Mill.), Eur. J. Agron. 21, 117-127.

Holz G., Coertze S., Williamson B. (2004) the ecology of Botrytis on plant surfaces, in: Elad Y., Tudzynski P., Delen N. (Eds.), Botrytis: Biology, Pathology and Control, Kluwer Academic Publishers, Dordrecht, the Netherlands, pp. 9-27.

Locascio S.J. (2005) Management of irrigation for vegetables: past, present, and future, HorTechnology 15, 482-485.

Madden L.V., Hughes G., van den Bosch F. (2007) The study of plant disease epidemics, APS press, Minnesota, USA.

Meneses J.F., Monteiro A.A., Abreu P.E. (1994) Influence of two different natural ventilation methods on greenhouse climate, tomato production and Botrytis control, Plasticulture 101, 3-12.

Miyamoto S., Piela K., Petticrew J. (1986) Seedling mortality of several crops induced by root, stem or leaf exposure to salts, Irrigation Sci. 2, 97-102.

Nischwitz C., Olsen M., Rasmussen S. (2004) Effect of irrigation type on inoculum density of Macrophomina phaseolina in Melon fields in Arizona, J. Phytopathol. 152, 133-137.

O’Neill T.M., Shtienberg D., Elad Y. (1997) Effect of some host and microclimate factors on infection of tomato stems by Botrytis cinerea, Plant Dis. 81, 36-40.

Ristaino J.B., Duniway J.M., Marois J.J. (1988) Influence of frequency and duration of furrow irrigation on the development 
of Phytophtora root rot and yield in processing tomatoes, Phytopathology 78, 1701-1706.

Rotem J., Palti J. (1969) Irrigation and plant diseases, Annu. Rev. Phytopathol. 7, 267-288.

Rotem J., Palti J., Lomas J. (1970) Effects of sprinkler irrigation at various times of the day on development of potato late blight, Phytopathology 60, 839-843.

Scherm H., van Bruggen A.H.C. (1995) Comparative study of microclimate and Downy mildew development in subsurface drip-and furrow- irrigated lettuce fields in California, Plant Dis. 79, 620-625.

Shtienberg D., Elad Y., Niv A., Nitzani Y., Kirshner B. (1998) Significance of leaf infection by Botrytis cinerea in stem rotting of tomatoes grown in non-heated greenhouses, Eur. J. Plant Pathol. 104, 753-763.

Sigandhupe R.B., Rao G.G.S.N., Patil N.G., Brahmanand P.S. (2003) Fertgation studies and irrigation scheduling in drip irrigation system in tomato crop (Lycopersicon esculentum Mill.), Eur. J. Agron. $19,327-340$.

Subbarao K.V., Hubbard J.C., Schulbach K.F. (1997) Comparison of lettuce diseases and yield under subsurface drip and furrow irrigation, Phytopathology 87, 877-883.
Sutton K.F., Lanini T.W., Mitchell J.P., Miyao E.M., Shrestha A. (2006) Weed control, yield, and quality of processing tomato production under different irrigation, tillage, and herbicide systems, Weed Technol. 20, 831-838.

Tiwari K.N., Singh A., Mal P.K. (2003) Effect of drip irrigation on yield of cabbage (Brassica oleracea $\mathrm{L}$. var. capitata) under mulch and no mulch conditions, Agr. Water Manage. 58, 19-28.

Wang S., Boulard T. (2000) measurement and prediction of solar radiation distribution in full-scale greenhouse tunnels, Agronomie 20, 41-50.

Wu B.M., Subbarao K.V. (2003) Effects of irrigation and tillage on temporal and spacial dynamics of Sclerotinia minor sclerotia and lettuce drop incidence, Phytopathology 93, 1572-1580.

Xiao C.L., Subbarao K.V., Schulbach K.F, Koike S.T. (1998) Effects of crop rotation and irrigation on Verticillium dahliae microsclerotia in soil and wilt in cauliflower, Phytopathology 88, 1046-1055.

Xie J., Cardena E.S., Sammis T.W., Wall M.M., Lindsey D.L., Murray L.W. (1999) Effects of irrigation method on chile pepper yield and Phytophthora root rot incidence, Agr. Water Manage. 42, 127-142.

Yohannes F., Tadesse T. (1998) Effect of drip and furrow irrigation and plant spacing on yield of tomato at Dire Dawa, Ethiopia, Agr. Water Manage. 35, 201-207. 